\title{
Diagnosis of the Availability of Groundwater Resources for Off-season Irrigation on the Pic of Sindou Rice Perimeter in Burkina Faso
}

\author{
Bama Nati Aïssata Delphine $e^{1, ~ *, ~ B a r k e ́ ~ G u i d a ~ H a b i b a ~}{ }^{2}$, Koita Mahamadou², Niang Dial², \\ Yacouba Hamma ${ }^{2}$ \\ ${ }^{1}$ Plant Production Department, Institute for the Environment and Agricultural Research (INERA), Ouagadougou, Burkina Faso \\ ${ }^{2}$ Hydro- Systems and Agriculture Water Laborator, International Institute for Water and Environmental Engineering (2iE), Ouagadougou, \\ Burkina Faso
}

\author{
Email address: \\ nati_aissata@yahoo.fr (B. N. A. Delphine), nati.aissata@gmail.com (B. N. A. Delphine) \\ ${ }^{*}$ Corresponding author
}

\section{To cite this article:}

Bama Nati Aïssata Delphine, Barké Guida Habiba, Koita Mahamadou, Niang Dial, Yacouba Hamma. Diagnosis of the Availability of Groundwater Resources for Off-season Irrigation on the Pic of Sindou Rice Perimeter in Burkina Faso. American Journal of Water Science and Engineering. Vol. 6, No. 2, 2020, pp. 60-64. doi: 10.11648/j.ajwse.20200602.11

Received: March 13, 2020; Accepted: March 31, 2020; Published: April 14, 2020

\begin{abstract}
In Burkina Faso, more precisely, in the Cascades region, on the Pic of Sindou rice perimeter, producers made dike to channel water from overflow springs for off-season irrigation. However, this perimeter like most of the developed areas in the country is subject to the scarcity of water resources to carry out off-season activities. The objective of this study was therefore to analyze the problem of water on the Pic of Sindou rice perimeter in order to propose solutions to overcome the lack of water. The estimation of the volume of water taken from the aquifer, through the springs for off-season irrigation was made using the volumetric method and surveys of 200 producers on their method of managing irrigation during February-July 2019. Gross irrigation water requirements were determined using climatic data from the Karfiguela station. And, the method of the water table fluctuation from 2016 to 2019 is used to estimate the variation of the groundwater stock. Gross irrigation water requirements are currently satisfied at $8.3 \%$, hence the inability of the four springs to cover production on the 260 hectare developed. The diagnosis also revealed that approximately $20 \%$ of the volume of water transported in the channels evaporates or infiltrates into the soil; $15 \%$ of spring water is not channeled and $18 \%$ is lost during off hours. However, the analysis of the variation of the groundwater stock revealed the existence of a groundwater reserve which can be mobilized by catchment works to satisfy the water deficit currently on the perimeter and even cover the extension of the perimeter to 300 hectare of available area.
\end{abstract}

Keywords: Spring, Water Shortage, Off-season Rice Production, Peasant Development, Sindou Pic Rice Perimeter

\section{Introduction}

Population growth has a proven influence on food availability in Africa [1-4]. This impact can be all the more harmful since agricultural growth does not keep pace with that of the population [2]. Added to this, the effect of rainfall variability which reduces harvests because rain is an essential determinant of agricultural productivity in West Africa [5-8]. It is in this context that producers are forced to exploit water points to produce during the off-season in order to palliate to the production deficit in the rainy season $[9,10]$. In Burkina
Faso, more precisely, in the Cascades region, on the Pic of Sindou rice perimeter, producers made dike to channel water from overflow springs for off-season irrigation. However, this perimeter like most of the developed areas in the country is subject to the scarcity of water resources to carry out offseason activities [11-13]. The objective of this study was therefore to analyze the problem of water on the Pic of Sindou rice perimeter in order to propose solutions to overcome the lack of water 


\section{Material et Method}

\subsection{Presentation of the Study Area}

The study area, around 400 hectare is located in the Cascades region, behind the Pic of Sindou (10³9'31' N and $\left.5^{\circ} 9^{\prime} 57^{\prime \prime} \mathrm{W}\right)$ in Burkina Faso. Irrigation water comes from four overflow springs (figure 1). The climate is tropical South Sudanese type with an average annual rainfall varying between $900 \mathrm{~mm}$ and $1200 \mathrm{~mm}$. According to [14], the Cascades region, in which the Pic of Sindou rice perimeter is located comprises two large hydrogeological sets: a set of basement rocks where the aquifer system consists of three superimposed aquifers and a sedimentary set with aquifers of the Kawara-sindou sand stones and Glauconieux fine sand stones $[15,16]$. The Pic of Sindou rice perimeter is subdivided into three parts exploited by the villages of Sindou, Douna and Niofila (Figure 1). The speculations produced on the perimeter in the off-season are rice and okra. Irrigation is done by gravity in earth channels made by producers and the plots are delimited by dike.

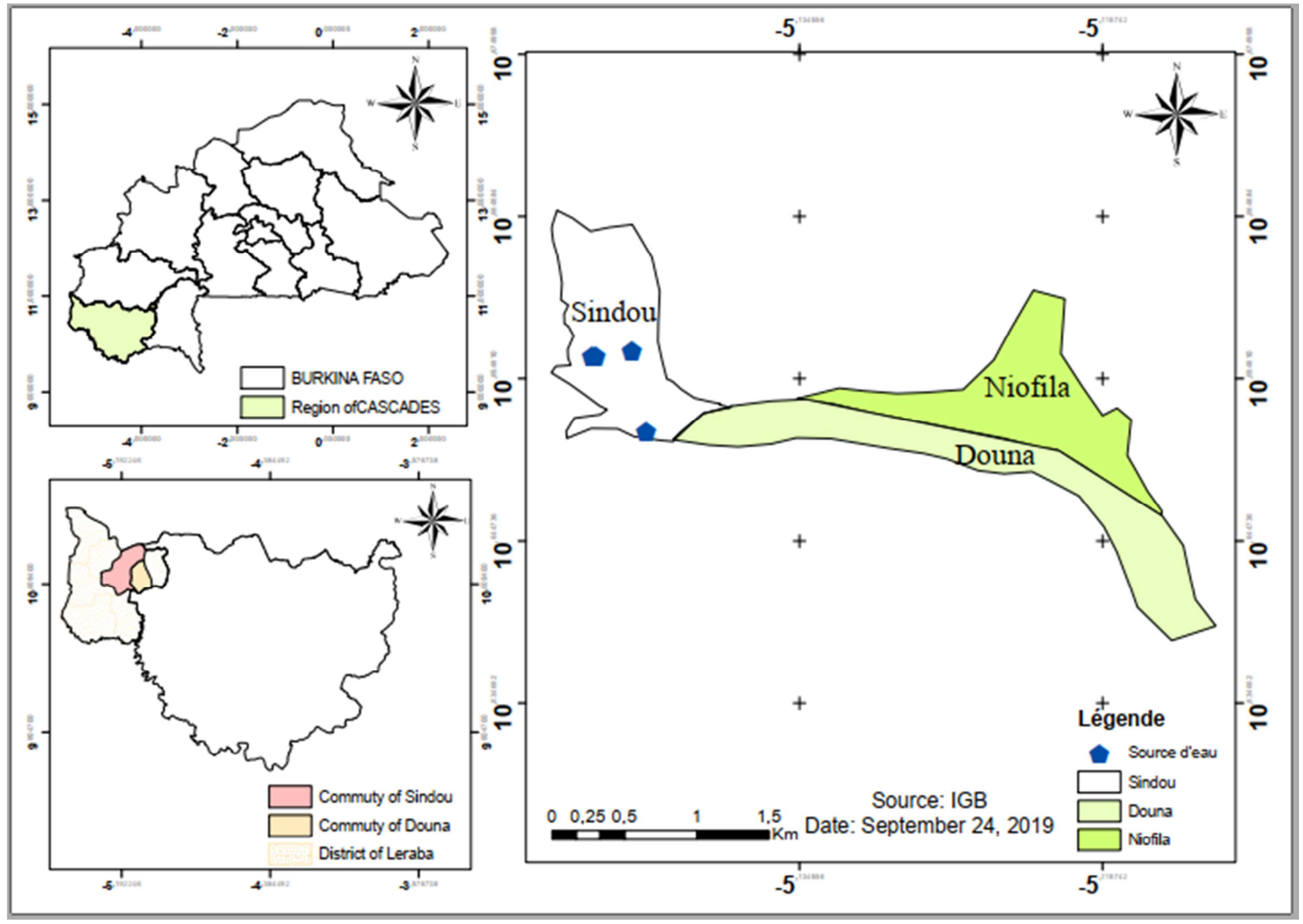

Figure 1. Localization of the Pic of Sindou rice perimeter.

\subsection{Calculation of the Volume of Water Supplied by Springs Intended for Off-season Irrigation}

The estimation of the volume of water taken from the aquifer, through the springs for off-season irrigation was done using the volumetric method and surveys of 200 producers on their management method in irrigation during February-July 2019. Flow measurements were made at the spring exit at the level of the main channel and at the entry of the plots daily at the level of each part of the perimeter. The volume of water withdrawn is calculated using the following formula (1):

$$
V_{E P}\left(m^{3}\right)=q\left(m^{3} / h\right) \times N_{h} \times N_{j} \times N_{s} \times N_{p}
$$

With: $\mathrm{V}_{\mathrm{EP}}$ : volume of water withdrawn during the offseason 2019;

q: average hourly flow entering in the plot;
$\mathrm{N}_{\mathrm{j}}$ : number of days of weekly irrigation;

$\mathrm{N}_{\mathrm{h}}$ : number of hours of irrigation;

$\mathrm{N}_{\mathrm{s}}$ : number of weeks per off-season;

$\mathrm{N}_{\mathrm{p}}$ : number of plots.

\subsection{Estimation of the Water Requirements for the Rice Irrigation During the Off-season 2019 on the Pic of Sindou Rice Perimeter}

The primary vocation of the perimeter being the production of rice, only the water needs of the rice will be taken into account in the calculation. Gross needs for irrigation water (formula (2) below) correspond to amount of water that must really be mobilized to meet needs in addition to losses.

$$
B_{B E}\left(m^{3}\right)=\frac{B_{N\left(m^{3}\right)}}{E_{i g}(\%)}=\frac{\left(E T M-P_{e}\right)(m) \times A\left(m^{2}\right)}{\left(E_{a} \times E_{d}\right)(\%)}
$$


With: $\mathrm{B}_{\mathrm{BE}}$ : gross need for irrigation water;

$\mathrm{B}_{\mathrm{N}}$ : net requirement;

$\mathrm{E}_{\mathrm{ig}}$ : overall irrigation efficiency, $48 \%$;

$\mathrm{E}_{\mathrm{a}}$ : application efficiency $60 \%$;

$\mathrm{E}_{\mathrm{d}}$ : channel distribution efficiency $80 \%$ because medium channels in clay-loam;

A: planted area, 260 ha;

ETM: maximum evapotranspiration

The ETM (Following formula (3)) is calculated from the reference evapotranspiration $\left(\mathrm{ET}_{0}\right)$ and the cultural coefficient $(\mathrm{Kc})$

$$
\operatorname{ETM}(\mathrm{mm})=K_{c} \times E T_{o}(\mathrm{~mm})
$$

$\mathrm{ET}_{0}$ or potentiale vapotranspiration was determined by the modified Penman method, using climatic data from the Karfiguela climatic station about $55 \mathrm{~km}$ from the site.

The values of Kc: $0.7 ; 0.5 ; 1.05$ and 0.7 during the months of February to May.

\subsection{Estimation of the Variation of the Groundwater Stock}

The fluctuation observed from 2016-2019 at the level of the two piezometers of the National Office for Water and Sanitation present in the city of Sindou were used to estimate the variation of the stock of groundwater using the following equation (4):

$$
\Delta S(m m)=\frac{\Delta h(m m)}{\Delta t} \times n_{e}
$$

With: $\Delta \mathrm{s}$ : the variation of stock of groundwater;

$\Delta \mathrm{h}$ : average of monthly variations in positives charges piezometric;

$\Delta \mathrm{t}$ : foreshore time in months;

$\mathrm{n}_{\mathrm{e}}$ : effective porosity of the aquifer, $0.4 \%$ [15]

\section{Results and Discussion}

\subsection{Estimation of the Capacity of the Springs}

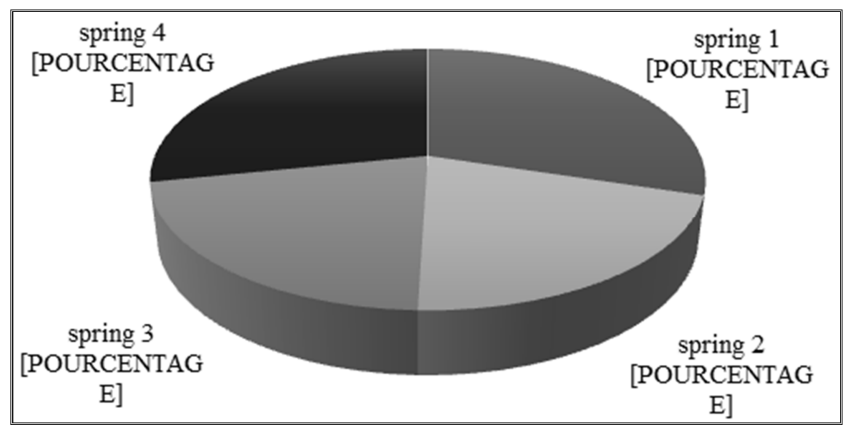

Figure 2. Distribution of the volume shares provided by each spring.

The results of the calculation of springs capacity in terms of volume supplied are shown in Figure 2. The total average water volume supplied by the four springs during the offseason amounts to $175,993.20 \mathrm{~m}^{3}$. In view of these results, it can be confirmed take of the small farmers that spring 1 is the main spring because it provides more volume of water than the other 3 . It supplies $52,388 \mathrm{~m}^{3}(30 \%)$ (Figure 2).

\subsection{Volume of Water Withdrawn During the Off-season for Rice Growing}

The investigation revealed that on the Sindou part of the perimeter, the plots are filled with water twice a week for three hours. The plots belonging to the small farmers of Douna and Niofila are irrigated three times a week for four and five hours, respectively for the Douna and Niofila part. Irrigation is stopped two weeks before harvest. The total volume of water with drawn for rice growing amounted to $149184 \mathrm{~m}^{3}$ for an area of 260 hectare. We also note that the largest sample is taken from the Douna section with a rate of $49 \%$ (Figure 3 ). This can be explained by the fact that it has the largest area. As for the Sindou and Niofila parts, they have respective rates of $33 \%$ and $18 \%$ (Figure 3 ). The low volume of the Niofila part can be explained by the low rate of the flowing water.

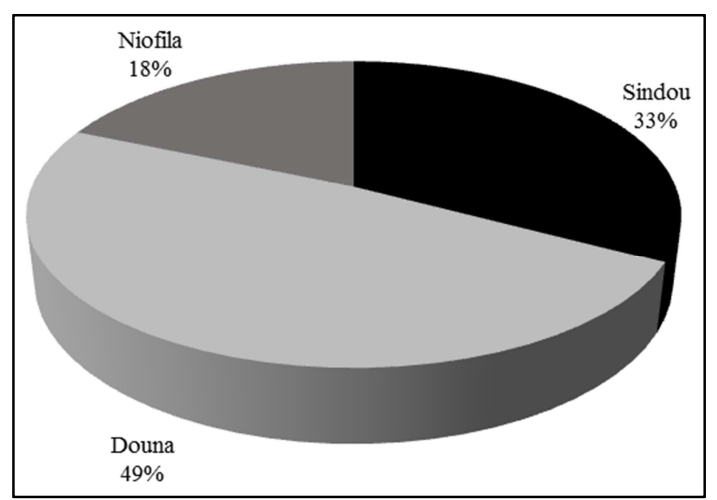

Figure 3. Distribution of the volume of water withdrawn by part of the Sindou peak rice perimeter.

\subsection{Water Need for the Irrigation During Off-season 2019 on the Sindou Peak Rice Perimeter}

Gross volumes of water for the irrigation of rice during the off-season amounted to $1807363 \mathrm{~m}^{3}$ (Table 1).

Table 1. Gross needs of irrigation water for the off-season.

\begin{tabular}{lllll}
\hline & February & March & April & May \\
\hline ETM $(\mathrm{mm})$ & 104.08 & 75.95 & 145.53 & 96.13 \\
Pe $(\mathrm{mm})$ & 1.00 & 19.50 & 8.80 & 58.72 \\
BN $(\mathrm{m})$ & 0.10 & 0.06 & 0.14 & 0.04 \\
$\mathrm{~A}\left(\mathrm{~m}^{2}\right)$ & 2600000 & 2600000 & 2600000 & 2600000 \\
BN $(\mathrm{m} 3)$ & 268 & 147 & 355 & 97 \\
Eig $(\%)$ & 0,48 & 0,48 & 0,48 & 0,48 \\
BB $(\mathrm{m} 3)$ & 558 & 306 & 741 & 203 \\
Total BN $(\mathrm{m} 3)$ & 867,868 & & & \\
Total BB $(\mathrm{m} 3)$ & 1807363 & & & \\
\hline
\end{tabular}

\subsection{Variation of the Stock of Groundwater}

Results of the estimation of the variation of the groundwater stock by using the method of fluctuation of the piezometric surface are recorded in Table 2. The inter annual average of the positive groundwater stock variations in the two piezometers is equal to $8.60 \mathrm{~mm}$ corresponding to a 
regulatory reserve of $9,747,616 \mathrm{~m}^{3}$.

Table 2. Variation of the stock of groundwater.

\begin{tabular}{|c|c|c|c|c|c|c|}
\hline $\begin{array}{l}\text { Name of the } \\
\text { piezometer }\end{array}$ & Year & $\begin{array}{l}\text { Cumulative positive } \\
\text { piezometric variations } \Delta \mathrm{h} \\
\text { (mm/year) }\end{array}$ & $\begin{array}{l}\text { Effective } \\
\text { Porosity }\end{array}$ & $\begin{array}{l}\text { Variation of the } \\
\text { water stock d'eau } \\
\Delta \mathbf{S}(\mathbf{m m})\end{array}$ & $\begin{array}{l}\text { Surface of the catchment } \\
\text { area }\left(10^{3} \mathrm{~m}^{2}\right)\end{array}$ & $\begin{array}{l}\text { Renewed reserve } \\
\left(\mathrm{m}^{3}\right)\end{array}$ \\
\hline \multirow{3}{*}{ SE2 } & $2016 \quad 2017$ & 1260.000 & 0.004 & 4.788 & 1134400 & 5431507 \\
\hline & $2017 \quad 2018$ & 1407.500 & 0.004 & 5.349 & 1134400 & 6067338 \\
\hline & 2018_2019 & 1270.000 & 0.004 & 4.826 & 1134400 & 5474614 \\
\hline \multirow{3}{*}{ SE3 } & 2016_2017 & 2540.000 & 0.004 & 9.652 & 1134400 & 10949229 \\
\hline & 2017_2018 & 2690.000 & 0.004 & 10.222 & 1134400 & 11595837 \\
\hline & 2018_2019 & 4400.000 & 0.004 & 16.720 & 1134400 & 18967168 \\
\hline Moyenne & & & & 8.593 & & 9747616 \\
\hline
\end{tabular}

\subsection{Discussion}

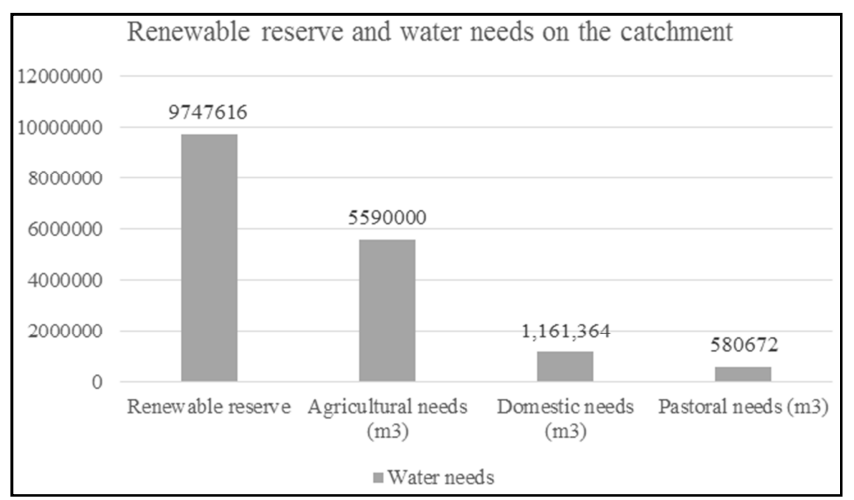

Figure 4. Renewable reserve and water requirements on the eastern Leraba catchment area in Gouindougouba.

Gross irrigation water requirements for the 260 hectare exceed the volume of water withdrawn for irrigation by $1,658,179 \mathrm{~m}^{3}$, representing a satisfaction rate of $8.3 \%$. The four springs, therefore, cannot meet the water needs of rice on 260 hectare currently developed by producers. However, it will be necessary to recognize the contribution of local knowledge in the management and sustainability of groundwater in off-season production $[17,18]$. Indeed, the use of groundwater for off-season irrigation has remained largely the responsibility of small producers in Sub-Saharan Africa [19]. In addition to the over estimation of the surface area, the earth channels made by the producers cause huge losses during transport. Indeed, the diagnosis revealed that approximately $20 \%$ of the volume of water transported in the channels evaporates or infiltrates into the soil; $15 \%$ of spring water is not channeled and $18 \%$ is lost during off hours. However, the variation of the groundwater stock over the past three years has made it possible to estimate the average renewable groundwater reserve at 9,747,616 $\mathrm{m}^{3}$ (Figure 4). When we decrease this volume, the domestic, pastoral and agricultural needs, because these are the main uses of groundwater in Africa, the remaining water stock is estimated at 2,415,580 $\mathrm{m}^{3}$. This stock will therefore be able to satisfy the current water deficit on the perimeter and even cover the extension of the perimeter to 300 hectare of the available area. The exploitation of this renewable reserve to meet the water needs of the perimeter is possible through direct withdrawals from the aquifer by carrying out catchment works including deep wells and boreholes.

\section{Conclusion}

The variation of the groundwater stock is estimated at 8.60 $\mathrm{mm} /$ year through the method of fluctuation of the piezometric surface. The evaluation of the gross irrigation water needs for off-season amounts to $1,807,363 \mathrm{~m}^{3}$ and water withdrawals are estimated at $149,184 \mathrm{~m}^{3}$ through the springs water which provide a volume of $175993 \mathrm{~m}^{3}$. We note the insufficiency of spring water to meet the water needs, but nevertheless, these needs can be satisfied by the regulatory reserve, in addition to an extension of the perimeter through direct pumping in the aquifer.

\section{Acknowledgements}

We express our gratitude to the provincial directorate of the National Office of Water and Sanitation, and the provincial directorate of the Ministry of Agriculture of Leraba for their frank collaboration within the framework of this study.

\section{References}

[1] Kevin Thomas, 2011. African Economic Conference, Addis ababa, Ethiopia, 25-28 october.

[2] FAO (2015). Rethinking Global Food Security and Sustainable Agriculture: From Europe to World. Being a Keynote Address delivered on behalf of Food and Agriculture Organisation by Mr Ren Wang, Assistant Director General of Agriculture and Consumer Protection Department on Tuesday, March 31, 2015.

[3] Xinchun, C.; Mengyan, W.; Xiangping, G.; Yalian, Z.; Yan, G.; Nan, W.; Weiguang, W. Assessing water scarcity in agricultural production system based on generalized water resources and water footprint framework. Sci. Total Environ. 2017, 609, 587-597. [Google Scholar] [CrossRef] [PubMed].

[4] Ogunniyi Adebayo, Omonona B. T, Abioye Oyewale, and Olagunju K. O. (2018). Impact of irrigation technology use on crop yield, crop income and household food security in Nigeria: A treatment effect approach. AIMS Agriculture and Food, 3 (2): 154-171. 
[5] Sultan, B., Janicot, S., Baron, C., Dingkuhn, M., Muller, M., Traoré, S. et Sarr, B. 2008. Les impacts agronomiques du climat en Afrique de l'Ouest: une illustration des problèmes majeurs. Sécheresse 19 (1): 29-37.

[6] TABET-AOUL M., BESSAOUD R. (2009), «Adapter les agricultures au changement climatique», MediTERRA, pp. 101-136.

[7] M. IDANI, A. A. AKINDELE, F. K. MEDEOU, E. OGOUWALE, Stratégies d'adaptation paysannes aux changements climatiques dans l'arrondissement de Dassari (Bénin, Afrique de l'Ouest): 291-294. In Boko M., Vissin E. W., Afouda S., «Climat Agriculture, Ressources en Eau d'hier à demain», Actes du XXVIème Colloque de l'AIC, Bénin, (2013), 573 p.

[8] SAMBOU P. C. (2015), Evolution climatique récente et stratégies d'adaptation des populations dans les arrondissements de Sakal et Ndande, dans la région de Louga, thèse de Doctorat unique, FLSH-UCAD, $456 \mathrm{p}$.

[9] Ouédraogo, M., Somé, L. et Dembélé, Y. 2010. Perceptions et stratégies d'adaptation aux changements des précipitations: cas des paysans du Burkina Faso. Sécheresse 2010; 21 n $^{\circ}$, avril-mai-juin 2010. pp. 87-96.

[10] Madjigoto, R. 2003. Des cultures pluviales à la culture de décrue: une adaptation du système de culture aux changements climatiques.

[11] Bélem P., Oscar A. (2013). Burkina Faso: La formation aux méthodes SRI améliore le quotidien des paysans de Bama, AGRIDAPE, Volume 29, $\mathrm{N}^{\circ} 1,6 \mathrm{p}-8 \mathrm{p}$.

[12] Wellens J., Nitcheu M., Sawadogo B., Diallo M., Traore F.,
Tychon B., 2009, Optimisation des calendriers d'irrigation pour le périmètre irrigué de lavallée du Kouà l'aide du logiciel SIMIS, $4 \mathrm{p}$.

[13] Bathily M. (2012). Evaluation des performances et diagnostic d'un système irrigué: cas de la Vallée du Kou au Burkina Faso, 76p.

[14] IWACO. (1993). Carte hydrogéologique du BURKINA FASO. Ouagadougou: Direction del'Inventaire des Ressources Hydrauliques (DIRH). Burkina Faso.

[15] DAKOURE, D. (2003). Eude hydrogéoloique et géochimique de la bordure Sud-Est du bassin sédimentaire de TAOUDENI (BURKINA FASO - MALI) - Essai de modélisation. Thèse de Doctorat, UniversitéParis VI - Pierre et Marie Curie. 255p.

[16] AEC\&M. (2016). Etude d'identification, de localisation et de caractérisation physique des sources d'eau dans les espaces de compétence des agences de l'eau du Mouhoun et des Cascades. Ouagadougou, Burkina Faso. Rapport final; 124p.

[17] Chadwick, M., Soussan, J., Mallick, D., Alam, S. Understanding Indigenous Knowledge: Its Role and Potential inWater Resource Management in Bangladesh; University of Leeds and Bangladesh Centre for Advanced Studies: Leeds, UK; Dhaka, Bangladesh, 1998.

[18] Megdal, S. B.; Eden, S.; Shamir, E. Water governance, stakeholder engagement, and sustainable water resources management. Water 2017, 9, 190. [CrossRef].

[19] Kwoyiga Lydia Kwoyiga and Stefan Catalin; 2018. Groundwater Development for Dry Season Irrigationin North East Ghana: The Place of Local Knowledge. Water 2018, 10, 1724; doi: 10.3390/w10121724. 